DOI:10.30842/ielcp230690152291

Andrey N. Sobolev

\title{
HYBRID GRAMMAR IN A MACEDONIAN DIALECT FROM ALBANIA ${ }^{1}$
}

\section{Гибридная грамматика в македонском диалекте в Албании}

Македонская диалектная речь в р-не Голо Бордо (Gollobordё) в Албании изобилует не только глубокими славянскими архаизмами, но и прогрессивными балканскими инновациями, среди которых особенно ценны свидетельства прямого материального и структурного грамматического влияния албанского языка. Кроме этих свидетельств, в статье представлен редкий окказиональный инновационный феномен - гибридная форма $n a$ d'efi баран-ACC.PL, отражающая прямое албанское влияние и открывающая доступ к «грамматическому мышлению» балканского двуязычного говорящего.

Ключевые слова: македонские диалекты, албанский язык, балканские инновации.

As long as there are no sufficient and absolutely adequate historical and linguistic sources on natural and spontaneous Balkan language evolution in the last 1000 years, we have, generally speaking, only the contemporary linguistic results of language change that can be set against our knowledge about the proto-stages of some language families. The crux of the question is, nevertheless, how to make use of linguistic methods to account for and distinguish prior structural changes that have resulted from contact to those which have resulted from internal development. The causes, actors, drivers, mechanisms, and stimuli of language integration and dis-integration, on the one hand, and barriers to these processes, on the other, often can not be directly observed, but generally must be reconstructed through linguistic research procedures. Specialists in language contact however find it difficult to «tease apart» the processes which have led to emergence of sprachbund, leaving the issue unsolved (Muysken 2013: 726).

Nevertheless there are extremely rare cases that allow the Balkan linguist to observe immediately at least a phase of the

\footnotetext{
${ }^{1}$ The research is supported by the Russian Scientific Foundation (project «Between separation and symbiosis: the languages and cultures of SouthEastern Europe in contact», Nr. 14-18-01405).
} 
integration process at work among significantly large groups of people, such as those in the zones of ongoing direct intimate language contact. Immediate observation of «contact at work» is possible in observation of speech behavior, when sufficient amounts of spontaneous speech, i.e. texts produced by representative bi- and monolingual informants, are available (cf. Adamou 2016). But still this kind of research remains a qualitative investigation of processes that are not easily quantified. One can observe the language contact in the community of the Muslim Gollobordas in Albania, where Slavic functions as L1 and Albanian as L2 (Sobolev, Novik 2013; Asenova 2016) ${ }^{2}$.

The parameters of the contact including power, prestige and range (Michaelis, Haspelmath 2014; Konior 2015) are as follows. The local Macedonian dialect (L1) is in contact with Standard Albanian (L2) with restrictions on age/gender groups (no knowledge of Albanian by elderly women and children up to 7); there is no standard Slavic language and almost no local Gheg Albanian dialect in usage. Albanians are the powerful group in the country, and the Slavs are the powerless. Standard Albanian is the modern state language, prestigious language of religion and prestigeuos emblematic language. Standard Albanian and to less extent the local Macedonian dialect are languages of wider communication in the region. The local Macedonian dialect is the indigenous minor language, the everyday language in the family and neighbourhood. Generally speaking, we have to do here with a bilingualism of a minority group, where the socially dominant country's official language possesses power prestige and the minority's language is linguistically dominant in speaker's linguistic competence (cf. van Coetsem 1988).

In phonetics and phonology there are no significant traces of any direct substantial Albanian influence on genetically Slavic lexical items. If phonetical substance is borrowed, it happens together with the albanian lexical item. Hence, there is no linguistic change in Macedonian L1 due to contact with Albanian as L2.

Occasionally one can hear back $[p]$ and labialized $[y]$ in words that are fully identical with Albanian ones due to common Balkan origin or borrowing from the same source such as Turkish. Their

\footnotetext{
${ }^{2}$ We possess a collection of the transcribed texts in the dialect, containing 9.500 word forms.
} 
morphological properties are inherently Slavic. To this group one can add onomatopoeia and generally phonetically deviant exclamations:

- [ $[$ ] n'p:na 'mother' (n'b:na m'oja 'imat k'azveno 'my mother said', generally [n'ana] or [n'zna]; $h b$ ! 'yes!';

- $[y]$ b'yreùsi PL 'baked filled pastry' (i te go rab'otaet t'amo za b'yreùsi pr'aet 'and they work it over to make b'yreùsi'), generally [b'urek]; onomatopeic pr:y!

Consonants, alien to Macedonian Slavic phonetics and phonology $(/ \theta /, / \delta /, / \lambda /, / t /)$, can be met only in two cases:

- in Albanian loanwords, often integrated morphologically into Macedonian, $/ \theta /, / \delta /, / \lambda /, \mid t /$ : dja $\theta$ 'cheese' (a be s'ega pospr'avjime $m^{\prime}$ alo djat 'and now we make some cheese', cf. Slavic s'iren'e 'cheese'); nd'od-e to happen-AOR.3SG ('ak i i 'akji mi nd'oðe 'so and so happened to me'); there are peripheral examples, such as vocatives: / $\lambda / \int t^{\prime} o$ prajf, o $p \lambda^{\prime} a k^{j} e$ ! 'how do you do, old lady!' and personal names: / $t / P \partial t^{\prime} u m b$ (cf. the Macedonized variant P'olum), litt. 'pigeon'; Datend'ifa, litt. 'swallow';

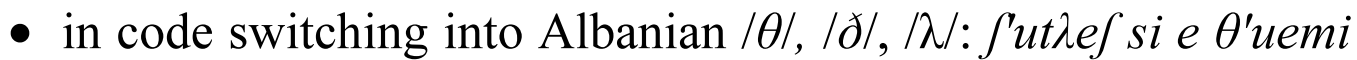

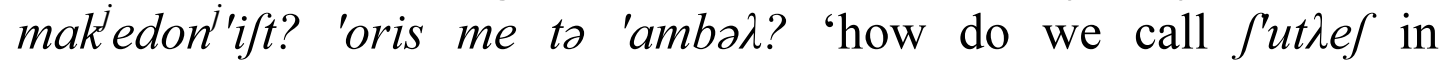
Macedonian, rice with sweets'; - o v'erdija! - urðər'o! 'o, Verdi! yes!? (at your service!)'.

Switching from Macedonian (L1) into Albanian (L2) is triggered by pragmatical or special communicative needs, there are no unmotivated instances. The competence in Albanian as L2 is fullyscaled. The phonetics of switching into Albanian and borrowing from Albanian is partially dialectally determined Gheg Albanian ('ambad 'sweet'; Datend'ifa personal name, litt. 'swallow'; $\theta$ 'uemi 'we say'; ðom-parat'om < Alb. dhomë paradhomë 'chamber') and partially Tosk or even Standard Albanian (to b'aftz m'irə! 'bon

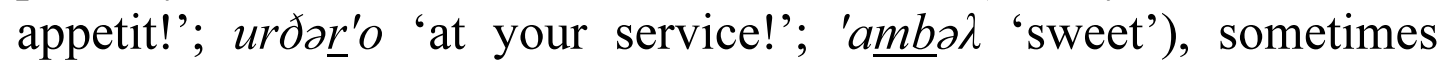
with Macedonian accent retraction ('oris $<$ Alb. or'iz 'rice').

Direct substantial albanian influence in grammar is almost absent. One can give the examples of the preverb p'ara 'over-' (n'e para kup'uaet '(They) don't buy very actively'), disjunctive conjunction 'ose 'or' ( $i$ ùce pom'in'it od'ovde m'eùjka, 'ose valk 'and a bear will come from here, or a wolf'), the affirmative particle $p o$ 'yes' and negative nuk 'no' in prohibitive: ej, n'uk-ajte! noIMPERAT.2PL, fully calquing the Albanian mos-ni! no-IMPERAT.2PL. 
The linguistic change in Macedonian L1 substance owing to contact with Albanian as L2 in the field of grammar is almost irrelevant, affecting only borrowing of synsemantical lexical units.

Hybrid phenomena in Macedonian L1 production are absolutely rare and can be met only in spontaneous speech, leaving the question of their systemic status rather unsolved until more and deeper research is done. Here are some striking examples in one short text (160 word forms) in Golo Bordo dialect of Macedonian, showing the simultaneous comprehensive interplay of Slavic, Albanian and Balkan Romannce, pan-Balkan and hybriid phenomena:

....s'amo 'eno d'ete 'imal. [...] mu o d'ade t'ع dete i mu r'eùfe, k'ei ùce se n'aprait dv'aeset g'odin'i, 'ovoi ùce o pr'aif k'urban. i toi ot'ide, k'u.rban ùce o prait. 'ama toi k'amberot naf, g'ospod za n'aize, za m'iie n'e. sme. ft'asan'i da o f'atime, mu 'isfarlat pred nego [...] 'oven. daf. d'eteto, v'elit, t'orn'i go, v'el' it, ùce o k'ol if 'oveno[t], d'afot.t. $i$ s'ea d'afof 'izleze za k'urban. i s'ega sv'ekoi n'ekoi, nap'imer 'ovie se br'ai ft 'imaet p'o.ùce... $k^{\prime}$ ol'et k'urban'i, i 'oviia k'urbanof se d'elvet s'ea po sirom'aite. se d'elvet po sirom'aite napr'imer vo s'elovo zn'aime m'ie 'en'i n'emaed br'ai. a za sv'ite za toi pr'aznik... t'oi veùfer za da 'imaed m'eso, i toi ùre im p'odel it. [...] 'eden piess go z'evaz za. s'ebe, 'ovijat fto k'olit k'urbanof. a tri pi'esoi. dr'ug'i p'odel'vet po sirom'aii. b'es pari, go d'avat t'a:ka. i za toi k'urbanot t'oa i'esti s'ea. [...] ja n'emam k'ol'eno. a toi b'abo 'imat k'ol'eno, 'imat d'el veno na d'efe.i. 'ima.'imano br'avi p'orano toi.

'...he had only one son. ...he gave that son to him and said: When he will be twenty years old, you will sacrfice him. And he went to sacrifice him. But our God, whom we cannot understand, throws a ram in front of him. Put the son aside, he says, you will slaughter the ram. And now the ram became the sacrifice. And now everybody, for example these people (will) have lots of small cattle, they slaughter the sacrifice, and this is distributed among the poor. It is distributed among the poor. For example, we know in the village some people do not have small cattle. And for all of us for that festival... this evening for everybody to have meat... and he will distribute among them. ...one part you take for yourself, the one who slaughters the sacrifice. And three other parts they distribute among the poor. With no money, they give it for free. And as for sacrifice, that is it. I did not slaughter, but my father did. He distributed rams. He has had small cattle before'.

There are some Slavic phenomena in the text which I refer to as antibalkanisms - linguistic properties that never get lost in Balkan 
Slavic and never propagate beyond Slavic in the Balkans regardless of any contact intensity (Sobolev 2011):

- stress retraction on prepositions: b'es pari [b'es=pari] WITHOUT=MONEY 'without money',

- verbal aspect of the Slavic type, marked by the verbal root itself: f'atime PF 'take' (vs. ); z'evas IPF 'take',

- the Slavic 1-particip (and l-perfect): 'imal 'to have'.

Some other phenomena show clearly dhe distance to Albanian:

- elisions, tolerated vowel groups, contractions: p'o:ùce < p'oveùce 'more'; s'ea 'now'; br'ai br'avi PL 'sheeps and goats',

- emphatic, phonologically insignificant lengh: k'u:rban k'urban 'sacrifice of a livestock animal', sirom'aite: sirom'aite PL 'poor people', $z a: \sim z a$ 'for' (cf. phonologically significant length in Gheg Albanian [Gjinari et al. 2007 I: 86, Harta 18]),

- no code-switching into Albanian L2.

On the other side, there are some phenomena in the text which go back to Albanian and Balkan Romance structural and lexical influence and which make the dialect's grammar system and vocabulary more compound and sophisticated, and finally significantly more alloglottic in the dialect continuum of Macedonian:

- postposition of attribute: $k^{\prime}$ amberot naf 'our prophet'; pi'esoi $d r^{\prime} u g^{j} i$ 'other parts',

- habeo-perfect, extended: 'ima 'imano 'he had' (cf. [Makarova 2017]),

- esse-perfect, highly idiosyncratic: $n^{\prime} e$ sme $\mathrm{ft}^{\prime} \mathrm{asan}^{\prime} i$ 'we are not capable of' (cf. Alb. s'jemi arritur),

- a highly idiosyncratic prepositional direct object: 'imat d'el'veno na d'efi '(They) distributed rams',

- lexical borrowings: pies SG, pi'esoi PL 'part' < Alb. pjes.

Hybrid phenomena, build of both a Slavic and an Albanian substance, can be observed in grammar, lexica and phraseology.

The most striking form in our data is na d'efi ram-ACC.PL. From the lexical point of view this is a direct material borrowing from Albanian dash [daf] 'ram', partially integrated into the morphology of Macedonian, cf. daf SG.INDEF, d'afof $\sim$ d'afot SG.DEF 'ram'. From the viepoint of plural building the expected form should sound *d'afovi * *d'afoi, like the above attested pies SG, pin'esoi PL 'part'. 
The speaker used two models with two substances simultaneously instead:

- the common Albanian morphosyntactic plural-marking model with apophony $a \sim e$, that is Albanian dash $\sim$ desh, which is completely alien to Slavic;

- the common slavic plural marker $-i$.

The addition of the preposition $n a$, following the Balkan Romance model (Sobolev 2008), to mark the direct object, finalizes the extraordinary highly redundant combination. Our conclusion is, that the degree of phonetical and grammatical adaptation of Albanian items into spontaneous speech in Macedonian is chosen by the Slavic speaker with great freedom, but no linguistic change happens, even not in statu nascendi. There is no doubt, that the bilingual hearers had no difficulties in decoding the form, but one can be assured, that it is highly unlikely to occur in a monolingual speech and will never be accepted and systematically reproduced by any monolingual Macedonian community.

As for hybrid phenomena in phraseology and lexica, one can point to the first component of ùfiz g'ozica (cf. Albanian qish bythën PRS IND, qifsh bythën OPT 'pedicabo in asino'), while lexically the reduplication 'oven daf SG.INDEF 'ram' and 'oveno[t] d'afot SG.DEF 'ram' (mu 'isfarlat pred nego 'oven daf... ùce o k'ol'if 'oveno[t], $\underline{d^{\prime} a f o t}$ 'throws a ram in front of him... you will slaughter the ram') attracts attention. We can interpret it as a compound of Slavic hyperonym and non-Slavic hyponym.

It is claimed, that two phonologies and two grammars coexist in the same bilingual individual, no single integrated speech community emerges with no creole, no mixed language, no emergence of new types, and there is no language death or abandoning of any language observable. The bilinguals in the Balkans seem not to be bored with «lightening the cognitive load of having to remember and use two different linguistic systems» (cf. Silva-Corvalán 1994: 6; Bisang 2006: 90). Our data show

(a) sophisticated, not simplified grammatical categories,

(b) forms, following highly idiosyncratic patterns,

(c) retention of synthetic archaisms.

Observations on the language of our bilingual informants, on one side, and their speech behaviour, on another side, show, however, that there is a gap with no strongly predictable or determinant 
relation between language and speech. In language the «one's own» L1 rules are applied to the «one's own» L1 substance which can be systematically sophisticated through borrowing and extended up to cross-linguistic clusters of terms. In speech behaviour involving actual interference, almost anything goes, e.g. the «alien» L2 substance can be used both with «alien» L2 or «one's own» L1 rules with a very different degree of transfer from one language to another and of integration into «one's own» L1. The effects of contact can be identified in bilingual speech behavior only if synchronically contrasted to a monolingual one. A prior contact-induced linguistic change seem to be identifiable in detecting retrospectively and opposing the prior bilingual and monolingual speech behavior. Unfortunately there is no adequate Balkan data available for any past period of time.

\section{Bibliography}

Adamou, E. 2016: A Corpus-Driven Approach to Language Contact. Endangered Languages in a Comparative Perspective. Boston; Berlin: De Gruyter Mouton.

Asenova, P. 2016 [2001]: Les interférences dans le dialecte de Golo bărdo - Albanie. Asenova, Petia. Izbrani statii po balkansko ezikoznanie [Selected papers in Balkan linguistics]. Sofia: Faber, 282-309.

Bisang, W. 2006: Contact-Induced Convergence: Typology and Areality. Brown, Keith (ed.). Encyclopedia of Language and Linguistics $\left(2^{\mathrm{n}}\right.$ edition). Oxford: Elsevier, 88-101.

van Coetsem, F. 1988: Loan Phonology and the Two Transfer types in Language Contact. Dordrecht: Foris.

Gjinari, J. Beci, B. Shkurtaj, Gj. Gosturani, Xh. 2007-008: Atlasi dialektologjik $i$ gjuhës shqipe [Albanian dialect atlas]. Vëllimi I-II. Napoli, Italy: Universita degli studi di Napoli l'Orientale; Tiranë: Akademia e shkencave e Shqipërisë.

Konior, D. V. 2015: Mezhdunarodnaya konferenciya «Grammaticheskaya gibridizaciya i socialnyye usloviya» [Grammatical hybridization and social conditions. Workshop. Leipzig 16-18 October 2014.]. Voprosy yazykoznaniya 3, 149-153.

Makarova, A. L. 2017. On the Macedonian Perfect(s) in the Balkan Context. Zeitschrift für Slawistik 62(3), 387-403.

Michaelis, S. M. Haspelmath, M. 2014: Introductory remarcs. Grammatical hybridization and social conditions. Workshop. Leipzig 16-18 October 2014. (Available online at http://www.eva.mpg.de/linguistics, Accessed on 2015-08-03).

Muysken, P. 2014: Language contact outcomes as the result of bilingual optimization strategies. Bilingualism: Language and Cognition. 16 (4): 709-730.

Silva-Corvalán, C. 1994: Language contact and change: Spanish in Los Angeles. Oxford: Clarendon Press. 
Sobolev, A. N. 2008: On some Aromanian Grammatical Patterns in the Balkan Slavonic Dialects. Sikimić, Biljana; Ašić, Tijana. (Eds.). The Romance Balkans. Belgrade: Balkanološki institut SANU, 113-121. Sobolev, A. N. 2011: Antibalkanizmy [Antibalkanisms]. Južnoslovenski filolog [South Slavic Philologist]. Knj. LXVII. Belgrade, 185-195.

Sobolev, A. Novik, A. (eds.) 2013: Golo Bordo / Gollobordë, Albaniya. [Golo Bordo / Gollobordë, Albania]. St. Petersburg: Nauka; Munich: Verlag Otto Sagner.

\section{A. N. Sobolev. Hybrid grammar in a Macedonian dialect from Albania}

The paper claims, that two phonologies and two grammars coexist in the same bilingual individual in Golo Bordo, no single integrated speech community emerges with no creole, no mixed language, no emergence of new types, and there is no language death or abandoning of any language observable.

Keywords: Standard Albanian, local Macedonian dialects, balkanisms 